\title{
Effect of Ethanol Extract Leaves of Nymphaea Lotus (Water Lily) on Fear and Anxiety Behaviour in Mice
}

\author{
Aduema $\mathrm{W}^{1}{ }^{*}$, Munachi $\mathrm{I}^{1}$ and Akunneh-Wariso $\mathrm{C}^{2}$ \\ ${ }^{1}$ Department of Human Physiology, Gregory University, Uturu, Abia State, Nigeria \\ ${ }^{2}$ Department of Human Physiology, Abia State University, Uturu, Abia State, Nigeria
}

${ }^{*}$ Corresponding author: Wadioni Aduema, Department of Human Physiology, Gregory University, Uturu, Abia State, Nigeria, Tel: +23408038046678; E-mail: wadioniaduema@gmail.com

Received: January 23, 2018; Accepted: February 24, 2018; Published: March 05, 2018

Citation: Aduema W, Munachi I, Akunneh-Wariso C (2018) Effect of Ethanol Extract Leaves of Nymphaea Lotus (Water Lily) on Fear and Anxiety Behaviour in Mice. Ann Clin Lab Res Vol.6: No.1: 223.

\section{Abstract}

The aim of this study was to investigate the effect of the leave extract of Nymphaea lotus on neuro-behaviour using mice as experimental model on fear/anxiety. Twenty seven mice weighing between 20-29 g were randomly selected into A, B and C groups for the study. Prior to the assessment of these neurobehavioral parameters, the phytochemical screening of the plant and the LD50 were analyzed. The elevated plus maze was used to access anxiety/fear related behaviours. Our findings showed that $N$. lotus extract reduces fear/anxiety related behavior, this was so because, the time spent in the open arm was increased significantly ( $p<0.01$ respectively) in the mice that were treated with the leave extract, the head dips showed similar results. However, the number of fecal boles, frequency of SAP and close arm duration were decreased in the mice treated groups compared to control $(p<0.01$ and $p<0.05$ respectively. In conclusion, the leaves of Nymphaea lotus may be responsible for the reduced level of anxiety and fear we found in the treated mice.

Keywords: Ethanol extract; Nymphaea lotus; Water lily; Fear; Anxiety behaviour; Mice

\section{Introduction}

Nymphaea lotus is a perennial plant that grows up to $45 \mathrm{~cm}$ in height; whose leaves float in water [1]. They are easily recognized by their aquatic habit, floating leaves, flamboyant flowers, several petals, many stamens and carpels and endospermous seeds with small embryo [2] This plant is mostly found in the Northern part of Nigeria. The plant contains many pharmacological and chemical important compounds which have been useful in the field of medicine [3]. Despite the immense technological advancement in modern medicine, many people still rely on traditional medicine and healing practices for their daily health practices $[4,5]$. This is owned to the fact that modern medicine leave resultant side effects coupled with the high cost in acquiring synthetic drugs. Moreover, there is an increasing incidence of neurobehavioral disorders among people of all ages. The side effects of many neuro-cognition enhancing drugs have left many individuals and patients with irreversible neurological damage [6]. This debilitating situation has led to the investigation of the medicinal properties of $N$. lotus. The validation of the therapeutic efficacy of $N$. lotus will provide novel means for the management/treatment of neurobehavioural disorders such as anxiety disorders [7-9].

\section{Materials and Methods}

\section{Animal care}

Twenty six (26) Swiss white mice were used in the study. The animals weighing between 20-29 g were housed in the Department of Physiology, Gregory University, Uturu for one week and later transported to the Department of Physiology, Abia state university, were they were kept for 14 day in a clean and well ventilated compartment for the animal to acclimatize before the experiment was carried out. The animals were feed properly and allowed drinking water adlibitum

\section{Experimental design}

The Twenty-six (26) Swiss mice were divided into three groups. A, B and C of 10 mice. Animals in group A received normal rodent chow and served as the control, group $B$ and group $C$ which serve as the low and high dose treated animals received $200 \mathrm{mg}$ and $400 \mathrm{mg} / \mathrm{kg}$ of the leave extracts for the number of days that the experiment lasted.

\section{Ethical approval}

All authors hereby declare that principle of Laboratory animal care was followed. All animals have been examined and approved by the appropriate ethics committee.

\section{Experimental procedure}

- Each mouse was picked from its tail and then placed in the centre square between the open and close arm of the apparatus. 
- Between each trial the apparatus is cleaned using a cotton wool soak in $70 \%$ ethyl alcohol in order to remove olfactory cues.

- Each mouse spent five minutes after which each mouse was removed from the apparatus and returned into their home cages.

Behaviors that were scored included: open arm entries (frequency and duration), closed arm entries (frequency and duration), head dipping, frequency of Stretch attend posture, grooming frequency, rearing; urination and defecation (number of fecal bole produced).

\section{Results}

\section{Duration in the open arm}

The open arm duration signifies the time spent by the mice in the open arm of the elevated plus maze (Figure 1) for the control, low dose and high dose diet of $N$. lotus which are $143.55 \pm 8.28 ; 179.44 \pm 4.71$ seconds and $181.55 \pm 10.72$ seconds respectively. The graph in Figure 2 shows that the treated groups of mice spent a higher time in the open arm when compared to control $(p<0.01)$.

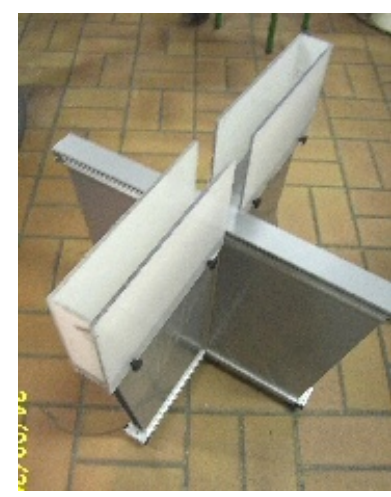

Figure 1 Elevated plus maze.

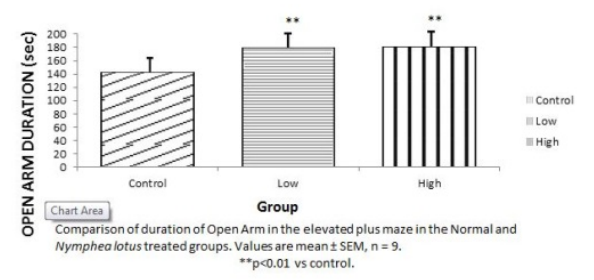

Figure 2 Comparison of duration of Open Arm in the elevated plus maze in the Normal and Nymphea lotus treated groups.

\section{Closed arm duration}

Figure 3 shows the close arm duration for the various groups, starting from the control, and then the treated groups (low and high dose). Their values were $147.88 \pm 4.17 ; 127.33 \pm$
4.10 and $127.33 \pm 2.19$ seconds respectively. The close arm duration for the treated mice were significantly lower $(\mathrm{P}<0.001)$ compared to control. However, there was no significant difference among the treated groups.

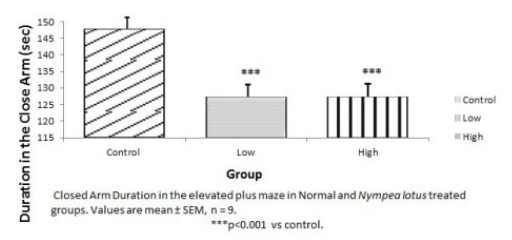

Figure 3 Closed arm duration in the elevated plus maze in normal and Nympea lotus treated groups.

\section{Frequency of head dips}

The frequency of head dips for the experimental animals were $9.88 \pm 1.91 ; 20.44 \pm 0.92 / 5$ mins and $20.88 \pm 2.40 / 5 \mathrm{~min}$ for mice fed control, low dose diet and high dose diet of $N$. lotus. The head dips for the mice administered the plant extract were higher when compared to the control $(P<0.001)$ (Figure 4).

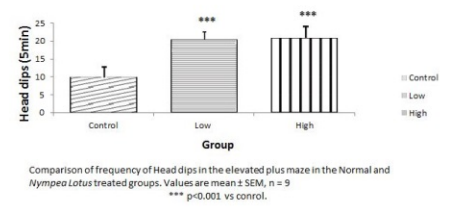

Figure 4 Comparison of frequency of Head dips in the elevated plus maze in the Normal and Nympea Lotus treated groups.

\section{Frequency of stretch attend posture}

The stretch attend posture values were found to be $4.00 \pm$ $0.50 ; 1.88 \pm 0.26$; and $1.89 \pm 0.20 / 5$ mins respectively. The stretch attend posture was statistically lower in the treated mice (low and high dose) of $N$. lotus $(\mathrm{P}<0.01, \mathrm{P}<0.001)$ compared to control (Figure 5).

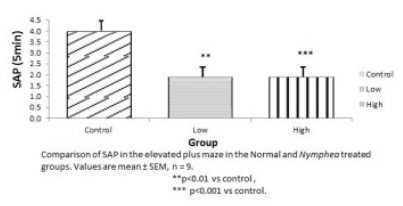

Figure 5 Comparison of SAP in the elevated plus maze in the Normal and Nymphea lotus treated groups. 


\section{Frequency of grooming}

Grooming frequency values for the mice fed control, low dose and high dose treated were $2.55 \pm 0.72 ; 2.44 \pm 0.72$ and $2.44 \pm 0.41 / 5$ mins respectively. Grooming frequency did not differ among the groups (Figure 6).

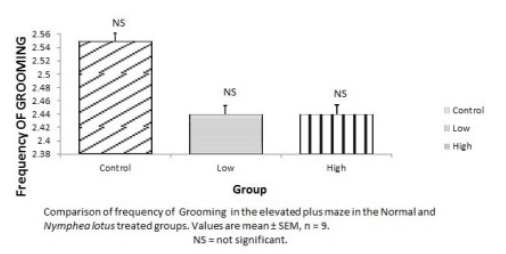

Figure 6 Comparison of frequency of grooming in the elevated plus maze in the normal and Nymphea lotus treated groups.

\section{Defaecation frequency}

Figure 7 compares the frequency of defecation among the groups. The values are: $2.88 \pm 0.42 ; 1.77 \pm 0.22$ and $1.00 \pm$ $0.23 / 5$ mins respectively. The number of boles in the group of mice fed low dose and high dose of $N$. lotus was statistically lower $(\mathrm{P}<0.05$ and $\mathrm{P}<0.01)$ compared to control.

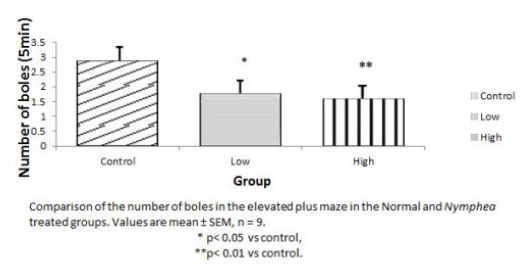

Figure 7 Comparison of the number of boles in the elevated plus maze in the normal and Nymphea lotus treated groups.

\section{Discussion}

The findings in the elevated plus maze shows that the treated mice turned out to be less fearful and anxious than the control because the treated mice spent more time in the open arm indicating absence of fear and anxiety [10]. The animals treated with doses of the extract also significantly spent less time in the arm that was closed, also indicating absence of anxiety/fear, the animals perhaps did not feel frightened from falling off the platform, thereby showing what the leaves of $N$. lotus can do, on the treated mice [11-14]. Findings from the elevated plus maze also showed that the animals treated with $N$. lotus extract had significantly more head dips [15]. Defecation frequency was significant less in the treated mice when compared to control, also indicating less anxiety and fear related behavior [16]. The amygdala control the level of Fear and anxiety mostly and the hypothalamus [17]. Stimulation of the amygdala for instance is associated with fear and feeling of terror in the animals [18]. Therefore, it is likely that the leaves of Nymphaea lotus contain a lot of chemical compounds, such as cardiac glycosides which has been reported to decrease contraction of the heart [19]. The leaves of Nymphaea lotus could be responsible for the anxiolytic properties found in the experimental animals my causing a decrease in the excitability of the cells of the amygdala, thereby increasing the level to which it response to stimuli, thus reducing the level of fear/ anxiety in the experimental animals $[20,21]$.

\section{Conclusion}

$N$. lotus reduces the level of fear/anxiety in animals. The plant also has low toxicity and reduced side effects, therefore pharmaceutical industries can use this plant in producing safe and efficient drugs for people with anxiety disorders. Based on the findings from this study, one can rightly say that $N$. lotus tends to have a significant effect on the nervous system by reducing the level of anxiety in animals. Therefore, cardiac glycoside which has been reported to decrease heart contraction and one of the constituents in $N$. lotus may be responsible for the decrease in anxiety/fear related behaviors in the experimental mice.

\section{Acknowledgement}

We acknowledged Mr. Uchenna Azunna and Mr. Nomso for their priceless support.

\section{References}

1. Abu-Zaida ME, Mashaly IA, AbdEI-Monem M, Torky M (2008) Economic potentials of some aquatic plants growing in North East Nile delta, Egypt. J Applied Sci 8: 1395-1405.

2. Afolayan AJ, Sharaibi OJ, Kazeem MI (2013) Phytochemical analysis and in vitro antioxidant activity of Nymphaea lotus. Int J Pharmacol 9: 297-304.

3. Akinjogunla OJ, Adegoke AA, Udokang IP, Adebayo-Tayo BC (2009) Microbial potential of Nymphaea lotus (Nymphaeaceae) against wound pathogens. J Med Plants Res. 3: 138-141.

4. Barlow DH (2001) Clinical handbook of psychological disorders (3rd edn). New York, NY: Guilford, USA.

5. Bourin $M$, Hascoet $M(2002)$ The mouse light/dark box test. Eur J pharmacol. 463: 55-65.

6. Carlini EA (2003) Plants and the central nervous system. Pharmacol Biochem Behav 75: 501-512.

7. Charles I, Shelton DO (2004) Diagnosis and management of anxiety disorders. J Am Osteopath Assoc 104: S2-S5.

8. Crawley JN (1985) Exploratory behaviour models of anxiety in mice. Neurosci Biobehav Rev 9: 37-44.

9. Cushnie TP, Lamb AJ (2005) Antimicrobial activities of flavonoids. Int J Antimicrobial Agents 26: 343.

10. Holmes A, Parmigiani S, Ferrari PF, Palanza P, Rodgers RJ (2000) Behavioral profile of wild mice in the elevated plus-maze test for anxiety. Physiol Behav 71: 509- 516.

11. Evans WC (1989) Trease and Evans Pharmacognosy. (13th edn), Bailere Traiadal, London. pp. 101-104. 
12. Jethro K (1994) Medicinal Plant Information. Back to Eden publishing CO, Lonia Linda, CA, USA. pp. 11- 276.

13. Kiehn O (2011) Development and functional organization of spinal locomotor circuits. Curr Opin Neurobiol

14. Kiehn O, Dougherty K (2013) Locomotion: Circuits and physiology. Springer Science + Business Media, LLC. pp. 46-48

15. Koofreh GD, Ekpenyong C, Nwangwa J, Antai AB (2012) Locomotor and exploratory behaviour in mice with treated oral artemether suspension. Research in Neuroscience 1: 17-24.

16. Hall CS (1934) Emotional behvior in the rat. 1. defecation and urination as measures of individual differences in emotionality. J Comp Psychol 18: 382-403.

17. Madhusudhanan N, Lakshmi T, Kumar SG, Venu G (2011) In vitro antioxidant and free radical scavenging activity of aqueous and ethanolic flower extract of Nymphaea alba. Int J Drug Dev Res 3: 252-258.
18. Rector N, Bourdeau D, Kitchen K, Joseph-Massiah L (2008) Anxiety disorders; an information guide. CAMH publications, Toronto, Canada.

19. Mohammed HA, Uka UN, Yauri YAB (2012) Evaluation of nutritional composition of water lily (Nymphaea lotus) from Tatabu flood plain, North-central Nigeria. J Fisheries Aquatic Sci 9: 37-44.

20. Costall B, Jones BJ, Kelly ME, Naylor RJ, Tomkins DM (1989) Exploration of mice in a black and white test box: Validation as a model of anxiety Pharmacol Biochem Behav 32: 777-785.

21. Elkins G, Rajab MH, Marcus J (2005) Complementary and alternative medicine use by psychiatric inpatients. Psychol Rep 96: 163-166. 